\title{
Silencing of anti-apoptotic transmembrane protein lifeguard sensitizes solid tumor cell lines MCF-7 and SW872 to perifosine-induced cell death activation
}

\author{
VESNA BUCAN, CLAUDIA Y.U.CHOI, ANDREA LAZARIDIS, PETER M. VOGT and KERSTIN REIMERS
}

Department of Plastic, Hand and Reconstructive Surgery, Medical School Hanover, D-30659 Hanover, Germany

Received October 25, 2010; Accepted January 14, 2011

DOI: $10.3892 / \mathrm{ol} .2011 .285$

\begin{abstract}
Lifeguard (LFG), an anti-apoptotic protein with high expression rates in breast cancer cells, has been identified as a molecule that inhibits death mediated by Fas. The molecular function of LFG and its regulation in the carcinogenesis of human breast and sarcoma cells, however, remains to be elucidated. In the present study, we investigated the ability of LFG expression to inhibit apoptosis induced by the alkylphospholipid perifosine. Results showed that LFG was able to be downregulated in selected sarcoma and breast cancer cell lines characterized by high endogenous LFG expression. A decreased LFG expression led to enhanced sensitivity to treatment with an agonistic Fas antibody or treatment with perifosine. Taken together, our findings indicate the role of LFG as an anti-apoptotic protein and provide further evidence of the potential of LFG as a target for the development of novel therapeutic strategies.
\end{abstract}

\section{Introduction}

Lifeguard (LFG), a member of a unique gene family with high structural similarity (1), was isolated and identified as a molecule that inhibits death mediated by Fas in tumor cells (2). The anti-apoptotic role of LFG was confirmed in LN-18 astrocytoma, and cervical carcinoma HeLa and Jurkat $\mathrm{T}$ cell lines (3). However, the exact role of LFG in apoptosis remains to be determined. While it has been shown that LFG interacts with Bax and localizes in cellular membranes, including the endoplasmic reticulum and plasma membrane (4), it is well documented that endogenous LFG localizes to lipid rafts (3). Its mode of action depends on Akt/protein kinase B (PKB) signaling as dominant negative Akt/PKB inhibits LFG activity, whereas the overexpression of constitutively active

Correspondence to: Dr Vesna Bucan, Klinik für Plastische, Hand- und Wiederherstellungschirurgie, Medizinische Hochschule, Carl-Neubergstr. 1, 30625 Hanover, Germany

E-mail: bucan.vesna@mh-hannover.de

Key words: apoptosis, lifeguard, Fas, perifosine, cancer
Act/PKB leads to an increase in LFG activity (3). Previously, it was found that LFG expression correlates with high tumor grades in primary breast tumors and that the expression of LFG mRNA in breast cancer depends on the activity of Akt/ LEF-1 signaling $(5,6)$.

Perifosine is an alkylphospholipid (APL), a novel class of antitumor agents, structurally related to ether lipids that interact with the cell membrane, thereby modulating intracellular growth signal transduction pathways. Notably, perifosine inhibits Akt/PKB activity, which is associated with activation of the stress-activated protein kinase (SAPK)/JNK pathway, without affecting PI3-K or PDK-1 activity (7). Perifosine was found to induce apoptotic cell death in a variety of tumor cell lines and cause inhibition of PC-3 prostate carcinoma cell growth. Perifosine induces p21WAF1 expression in squamous carcinoma cells through a p53-independent pathway, leading to the loss of cyclin-dependent kinase activity and cell cycle arrest $(7,8)$.

While it has been shown that the cellular uptake of perifosine is required in its role as an anticancer drug, the significance of lipid raft-mediated endocytosis has yet to be determined. Various studies have shown that perifosine accumulates in lipid rafts in a manner sensitive to raft disruption by cholesterol depletion (9-11). Subsequently, it was suggested that LFG, an anti-apoptotic protein with subcellular localization in lipid rafts, may interfere with perifosine-induced apoptosis. Thus, it was postulated that high expression rates of LFG confer resistance to perifosine-induced apoptosis and that downregulation of LFG expression sensitizes cell lines to this drug. Consequently, LFG expression was reduced in selected cellular models by small interfering (si)RNA transfection and the impact on perifosine-induced apoptosis was measured.

\section{Materials and methods}

Cell lines and culture condition. Human breast carcinoma MCF7 and liposarcoma carcinoma SW872 cell lines were obtained from the American Type Culture Collection (Rockville, MD, USA) and grown in Dulbecco's modified Eagle's medium (DMEM) (PAA, Cölbe, Germany) supplemented with $10 \%$ fetal calf serum (Biochrom, Berlin, Germany) and $50 \mathrm{mg} / \mathrm{ml}$ penicillin-streptomycin. Cultures were maintained at $37^{\circ} \mathrm{C}$ in a humidified atmosphere with $5 \% \mathrm{CO}_{2}$. 
Caspase assay. Activation of caspase-3/7 was determined using the Apo-One Homogeneous Caspase-3/7 assay (Promega, Madison, WI, USA) according to the manufacturer's instructions. Briefly, MCF-7 breast cancer and SW872 sarcoma

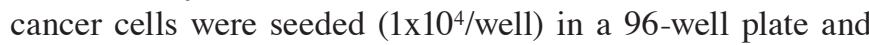
infected with siRNA LFG and control siRNA $\left[10^{7} \mathrm{VP}\right.$ (viral particles) $/ \mathrm{ml}$ ] for $48 \mathrm{~h}$. After $48 \mathrm{~h}$, the cells were incubated with either $25-50 \mathrm{ng} / \mathrm{ml}$ of agonistic anti-Fas (clone CH11) or $2.5-5 \mu \mathrm{M}$ of perifosine (soluble in water at $10 \mathrm{mg} / \mathrm{ml}$ ) for $4 \mathrm{~h}$. Following treatment, the cells were mixed with the same volume of Apo-One Homogeneous Caspase-3/7 reagent and incubated at room temperature for $2 \mathrm{~h}$. Caspase-3/7 activation was estimated from sample fluorescence at the excitation wavelength of $492 \mathrm{~nm}$ and the emission wavelength of $521 \mathrm{~nm}$ using the fluorescence plate reader Tecan GENios (Tecan Schweiz AB, Zurich, Switzerland).

Small interfering RNA. MCF-7 and SW873 cells were transfected with siRNA LFG-780 5'-gagcgggtgtatttacattg-3' and siRNA LFG-650 5'-cctcctaccettccaatatgt-3 (designed by Sirion, Munich, Germany) and the appropriate control vector. The algorithm used by Sirion for the siRNA design was optimized for maximum gene specificity and KD efficiency. Subsequent virus rescue and production were carried out in HEK 293 cells. Virus purification was performed using the ViraBind ${ }^{\mathrm{TM}}$ Adenovirus Miniprep kit (Cell Biolabs, Inc., USA). The cells were seeded at $2 \times 10^{4}$ cells $/ \mathrm{cm}^{2}$ and incubated at $37^{\circ} \mathrm{C}$ in a humidified atmosphere with $5 \% \mathrm{CO}_{2}$ for $48 \mathrm{~h}$ before being analyzed.

Real-time polymerase chain reaction (RT-PCR) analysis. Total RNA was extracted using the NucleoSpin RNAII kit (MN Macherey-Nagel, Duren, Germany). RNA (1 $\mu \mathrm{g})$ was then reverse transcribed into cDNA and amplified using the iScript $^{\mathrm{TM}}$ cDNA kit (Bio-Rad Laboratories, Hercules, CA, USA). The reverse (R) and forward (F) primers used were: LFG-F 5'-gactcatcctggccatcctcctac-3' and LFG-R 5'-ggcgtcggtt acccatcagc-3'; and 18S-F 5'-gagcggtcggegtcccccaacttc-3' and 18S-R 5'-gcgcgtgcagccecggacatctaa-3'. PCR was carried out in $20-\mu 1$ samples with $5 \mathrm{ng}$ cDNA and $10 \mathrm{pM}$ of each forward and reverse primer and the $2 \mathrm{X}$ SYBR-Green SensiMix DNA kit (Quantace, London, UK). Relative gene expression was determined by normalization of the fluorescence intensity to the expression of the $18 \mathrm{~S}$ gene. Amplification cycles were: 40 cycles at $94^{\circ} \mathrm{C}$ for $30 \mathrm{sec}, 65^{\circ} \mathrm{C}$ for $30 \mathrm{sec}$ and $72^{\circ} \mathrm{C}$ for $1 \mathrm{~min}$.

\section{Results}

To investigate the ability of LFG expression to suppress APL-induced apoptosis, two human solid tumor-derived cell lines with high endogenous LFG expression were selected: breast carcinoma MCF7 and liposarcoma SW872. Two siRNAs (650 and 780) were designed and tested for their silencing activity in MCF-7 and SW872 cells. Ad-sh-LFG-650 significantly decreased LFG mRNA as shown by semi-quantitative RT-PCR at $48 \mathrm{~h}$ following transfection (Fig. 1A).

We subsequently investigated whether downregulation of LFG expression leads to increased rates of apoptosis in the selected cell lines. The cells did not exhibit a significant

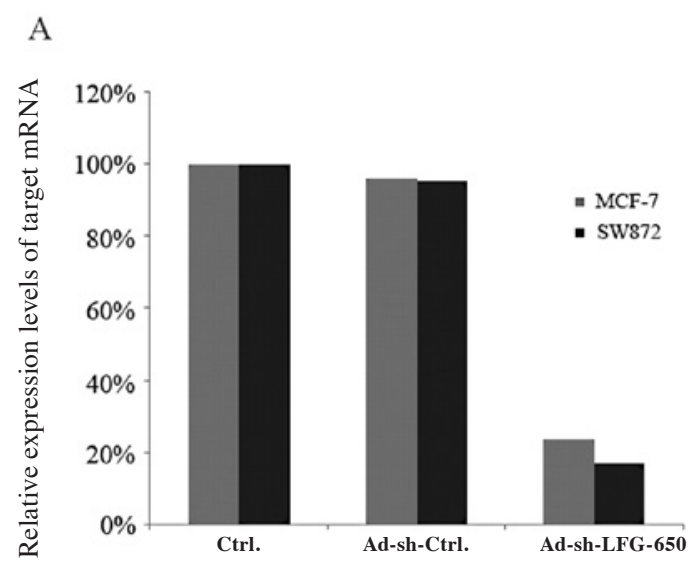

B

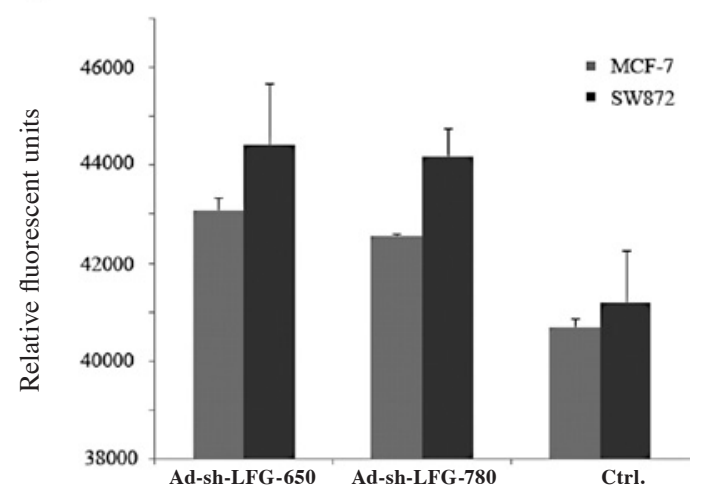

Figure 1. (A) Reduction in LFG mRNA $48 \mathrm{~h}$ after transfection with adenoviral vector as compared to the control cells. Semi-quantitative RT-PCR was carried out in 20- $\mu 1$ samples with 5 ng cDNA and 10 pmol of each forward and reverse primer using the $2 \mathrm{X}$ SYBR-Green Sensi-Mix DNA kit. The relative gene expression was determined from the fluorescence intensity ratio of the target gene to $18 \mathrm{~S}$. (B) The human breast carcinoma MCF-7 and liposarcoma SW872 cell lines were transfected with Ad-sh-LFG-650 and Ad-sh-LFG-780 vectors for $48 \mathrm{~h}$ and analyzed for activated levels of caspase 3 using the Apo-One assay. The data are the means \pm SD for triplicate determinations which were repeated in three separate experiments.

increase in cellular apoptosis over a 48-h period; the level of apoptosis remained at an almost constant level comparable to the control (Fig. 1B).

Since the LFG-mediated inhibition of Fas-induced cell death is well documented in the literature, we assessed the efficiency of LFG suppression on Fas-mediated apoptosis. MCF-7 and SW872 cancer cells were infected with Ad-sh-LFG-650 and the control siRNA $\left(10^{7} \mathrm{VP} / \mathrm{ml}\right)$ vector for $48 \mathrm{~h}$ followed by incubation with $25-50 \mathrm{ng} / \mathrm{ml}$ of agonistic anti-Fas (clone CH11) for an additional $4 \mathrm{~h}$. While a dose-dependent increase in apoptosis in the control cells indicated a general sensitivity of MCF-7 and SW872 cells to treatment with agonistic antiFas, we found that the cells with a downregulated expression of LFG exhhibited significantly increased rates of apoptosis (SW872: $\mathrm{P}=4.94581 \mathrm{E}-07, \mathrm{P}=1.7476 \mathrm{E}-07$; MCF7: $\mathrm{P}=2.9744 \mathrm{E}-05$, $\mathrm{P}=0.00282759)$ indicating an increase in sensitivity to the treatment (Fig. 2A and B).

Involvement of LFG in resistance against perifosinemediated apoptosis was assessed to test the effect of LFG downregulation in the cellular models. We transfected MCF-7 
A

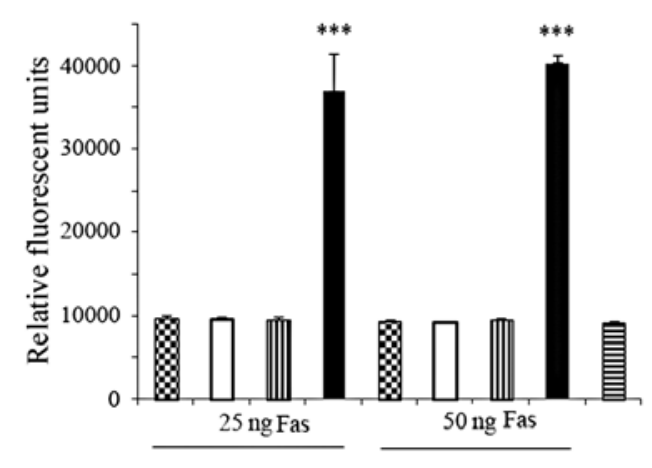

C

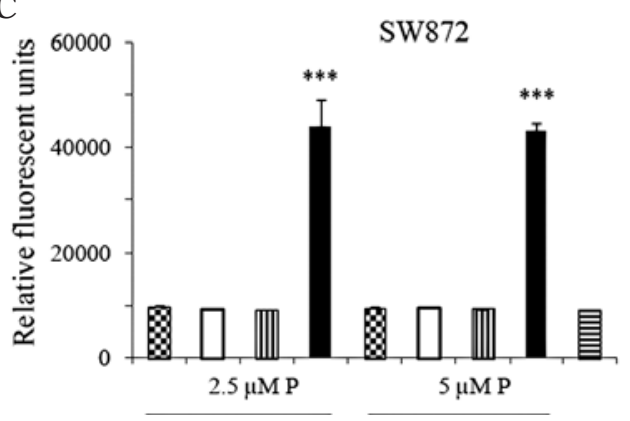

B

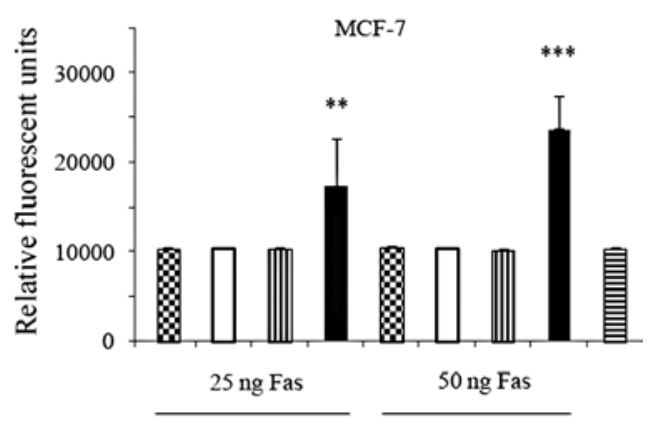

D

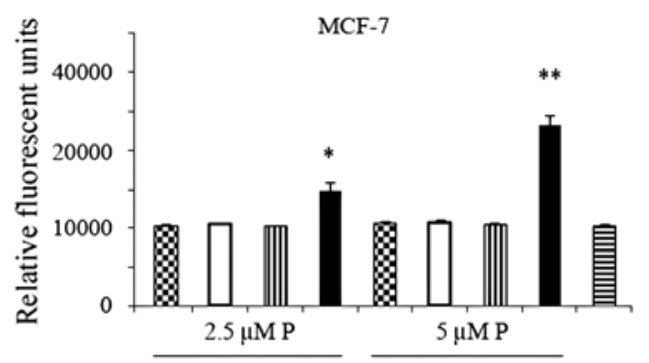

Figure 2. MCF-7 and SW872 cells were transfected with LFG-specific siRNA (Ad-sh-LFG-650) for 48 h. Non-transfected and Ad-sh-control vector-transfected cells were used as negative controls. Following transfection, the cells were treated with agonistic anti-Fas (clone CH11; 25-50 ng/ml) and perifosine (2.5-5 $\mu \mathrm{M})$. Apoptosis was quantified by measuring the levels of active caspase 3 using the Apo-One assay. (A) SW872 and (B) MCF-7 cells with downregulated LFG expression showed a statistically significant increase in apoptosis compared to the control when treated with Fas $(\mathrm{P}=4.94581 \mathrm{E}-07$, $\mathrm{P}=1.7476 \mathrm{E}-07$ and $\mathrm{P}=2.9744 \mathrm{E}-05, \mathrm{P}=0.00282759$, respectively). Transfected (C) SW872 and (D) MCF-7 cells showed a statistically significant increase in apoptosis compared to the control when treated with perifosine $(\mathrm{P})(\mathrm{P}=0.00029973, \mathrm{P}=0.00027001$ and $\mathrm{P}=0.04668954, \mathrm{P}=0.00152829$, respectively). Data are the means $\pm \mathrm{SD}$ of triplicate determinations which were repeated in three separate experiments. ${ }^{*} \mathrm{p}<0.05,{ }^{* * *} \mathrm{p}<0.01,{ }^{* * * *} \mathrm{p}<0.001$ vs. the control. Checkered bar, control; white bar, Ad-sh-conrol; vertical-striated bar, LFG vector; black bar, Ad-sh-LFG-650; horizontal-striated bar, untreated control.

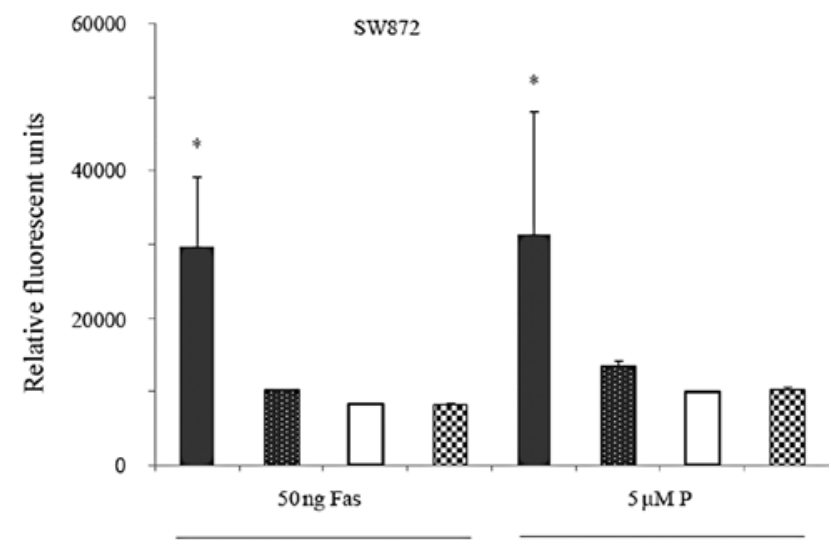

Figure 3. SW872 cells were transfected with the Ad-sh-LFG-650 vector for $48 \mathrm{~h}$ (downregulation). Cells were then transfected with the cDNA-LFG vector for the next $24 \mathrm{~h}$ (upexpression). Apoptosis was quantified by measuring the levels of active caspase 3 using the Apo-One assay. Data represent the means \pm SD for triplicate determinations which were repeated in three separate experiments. ${ }^{*} \mathrm{p}<0.05$ vs. the control. Black bar, Ad-sh-LFG-650; dotted bar, Ad-sh-LFG-650+LFG vector; white bar, Ad-sh-Ctrl.; checkered bar, control.

and SW872 cells with the Ad-sh-LFG-650 vector $48 \mathrm{~h}$ prior to perifosine treatment. Treatment of the transfected $\mathrm{MCF}-7$ and SW872 cells with $2.5-5 \mu \mathrm{M}$ perifosine for $4 \mathrm{~h}$ resulted in a significant increase in cell death compared to the control cells (SW872: $\mathrm{P}=0.00029973, \quad \mathrm{P}=0.00027001 ; \mathrm{MCF}-7$ : $\mathrm{P}=0.04668954, \mathrm{P}=0.00152829$ ) (Fig. 2C and D).

To test for specificity of the observed effect, we performed rescue experiments by first transfecting SW872 cells with the Ad-sh-LFG-650 vector (downregulation) for $48 \mathrm{~h}$ followed by an LFG-encoding expression vector for an additional $24 \mathrm{~h}$. Following the given time, cells were incubated with $50 \mathrm{ng} / \mathrm{ml}$ of agonistic anti-Fas (clone CH11) and $5 \mu \mathrm{M}$ of perifosine. Four hours after treatment, apoptosis rates were found to be significantly decreased in the LFG-transfected cells (Fig. 3).

\section{Discussion}

In the present study, we demonstrated that silencing of LFG expression increased apoptosis in Fas- and perifosine-treated MCF7 and SW872 cancer cells (Fig. 2). This is a significant finding as clinical phase II studies on perifosine for treatment of inoperable soft tissue sarcomas $(12,13)$ and metastatic breast cancer patients (14) are underway for the purpose of identifying sensitive tumor populations.

Although our data clearly revealed that LFG was able to reduce perifosine activity in the cell models, a number of issues require elucidation. Investigation of the cellular uptake of APL under given experimental conditions is warranted as uptake has been shown to be crucial to its antitumoral 
activity (10). Although different types of alkylphospholipids depend on the same modes of cellular uptake, it appears that observed differences in kinetics and efficiencies may depend on variations in the importance of singular pathways, e.g., raft-mediated endocytosis via ATP-dependent translocase activity $(15,16)$. This may explain differences in the biological activity of modified alkylphospholipids as found in the study by Mravljak et al (17) which confirms our results of reduced sensitivity of MCF-7 cells to treatment with perifosine.

It is crucial to determine whether prolonged treatment with perifosine induces any changes in the LFG expression since perofisone is a known regulator of survival and proliferation pathways, such as PI3K/Akt and ERK 1/2 $(7,18,19)$. Previously, we demonstrated that LFG is a new target gene of the Akt/LEF-1 pathway (6) and consequently a potential target of perifosine activity as well.

A number of studies aimed to sensitize cells to undergo apoptosis by reducing the levels of anti-apoptotic proteins, such as Bcl-2 and Bax-XL. In a large number of cell culture studies, antisense oligonucleotides have been used to block the expression of anti-apoptotic proteins, thereby sensitizing cells to chemotherapy (20-24). The results of these studies showed that altering the homeostasis of pro- and anti-apoptotic proteins can facilitate cell death, suggesting a potential therapeutic application of antisense oligonucleotides in the treatment of cancer. This is the first study to report an enhanced sensitivity to perifosine-mediated apoptosis following LFG downregulation in carcinoma cells. Collectively, these data show that LFG may serve as a target gene for developing new therapeutic strategies against certain types of cancer.

\section{Acknowledgements}

This study was funded by the Claudia-von-Schilling Breast Cancer Foundation and Niedersächsische Krebsgesellschaft. We are most grateful to AEterna Zentaris Inc. for providing perifosine. We also thank Dr Christine Radtke for the helpful discussion and critical reading of the manuscript and Nikolas Bautsch for the excellent technical assistance.

\section{References}

1. Hu L, Smith TF and Goldberger G: LFG: A candidate apoptosis regulatory gene family. Apoptosis 14: 1255-1265, 2009.

2. Somia NV, Schmitt MJ, Vetter DE, et al: LFG: an anti-apoptotic gene that provides protection from Fas-mediated cell death. Proc Natl Acad Sci USA 96: 12667-12672, 1999.

3. Beier CP, Wischhusen J, Gleichmann M, et al: FasL (CD95L/ APO-1L) resistance of neurons mediated by phosphatidylinositol 3-kinase-Akt/protein kinase B-dependent expression of lifeguard/neuronal membrane protein 35 . J Neurosci 25: 6765$6774,2005$.

4. Reimers K, Choi CY, Mau-Thek E, et al: Sequence analysis shows that Lifeguard belongs to a new evolutionarily conserved cytoprotective family. Int J Mol Med 18: 729-734, 2006.

5. Bucan V, Reimers K, Choi CY, et al: The anti-apoptotic protein lifeguard is expressed in breast cancer cells and tissues. Cell Mol Biol Lett 15: 296-310, 2010.
6. Bucan V, Adili MY, Choi CY, et al: Transactivation of lifeguard (LFG) by Akt-/LEF-1 pathway in MCF-7 and MDA-MB 231 human breast cancer cells. Apoptosis 15: 814-821, 2010.

7. Kondapaka SB, Singh SS, Dasmahapatra GP, et al: Perifosine, a novel alkylphospholipid, inhibits protein kinase B activation. Mol Cancer Ther 2: 1093-1103, 2003.

8. Patel V, Lahusen T, Sy T, et al: Perifosine, a novel alkylphospholipid, induces p21(WAF1) expression in squamous carcinoma cells through a p53-independent pathway, leading to loss in cyclin-dependent kinase activity and cell cycle arrest. Cancer Res 62: 1401-1409, 2002.

9. Gajate C and Mollinedo F: Edelfosine and perifosine induce selective apoptosis in multiple myeloma by recruitment of death receptors and downstream signaling molecules into lipid rafts. Blood 109: 711-719, 2007

10. Mollinedo F, de la Iglesia-Vicente J, Gajate C, et al: In vitro and in vivo selective antitumor activity of Edelfosine against mantle cell lymphoma and chronic lymphocytic leukemia involving lipid rafts. Clin Cancer Res 16: 2046-2054, 2010.

11. Van der Luit AH, Vink SR, Klarenbeek JB, et al: A new class of anticancer alkylphospholipids uses lipid rafts as membrane gateways to induce apoptosis in lymphoma cells. Mol Cancer Ther 6: 2337-2345, 2007.

12. Bailey HH, Mahoney MR, Ettinger DS, et al: Phase II study of daily oral perifosine in patients with advanced soft tissue sarcoma. Cancer 107: 2462-2467, 2006.

13. Knowling M, Blackstein M, Tozer R, et al: A phase II study of perifosine (D-21226) in patients with previously untreated metastatic or locally advanced soft tissue sarcoma: A National Cancer Institute of Canada Clinical Trials Group trial. Invest New Drugs 24: 435-439, 2006.

14. Leighl NB, Dent S, Clemons M, et al: A Phase II study of perifosine in advanced or metastatic breast cancer. Breast Cancer Res Treat 108: 87-92, 2008

15. Munoz-Martinez F, Torres C, Castanys S, et al: The anti-tumor alkylphospholipid perifosine is internalized by an ATP-dependent translocase activity across the plasma membrane of human KB carcinoma cells. Biochim Biophys Acta 1778: 530-540, 2008

16. Vink SR, van der Luit AH, Klarenbeek JB, et al: Lipid rafts and metabolic energy differentially determine uptake of anticancer alkylphospholipids in lymphoma versus carcinoma cells. Biochem Pharmacol 74: 1456-1465, 2007.

17. Mravljak J, Zeisig R and Pecar S: Synthesis and biological evaluation of spin-labeled alkylphospholipid analogs. J Med Chem 48: 6393-6399, 2005

18. Ruiter GA, Zerp SF, Bartelink H, et al: Anti-cancer alkyllysophospholipids inhibit the phosphatidylinositol 3-kinase-Akt/ PKB survival pathway. Anticancer Drugs 14: 167-173, 2003.

19. Vink SR, van Blitterswijk WJ, Schellens JH, et al: Rationale and clinical application of alkylphospholipid analogues in combination with radiotherapy. Cancer Treat Rev 33: 191-202, 2007.

20. Duggan BJ, Maxwell P, Kelly JD, et al: The effect of antisense $\mathrm{Bcl}-2$ oligonucleotides on $\mathrm{Bcl}-2$ protein expression and apoptosis in human bladder transitional cell carcinoma. J Urol 166: 1098-1105, 2001.

21. Li F, Srinivasan A, Wang Y, et al: Cell-specific induction of apoptosis by microinjection of cytochrome c. Bcl-xL has activity independent of cytochrome c release. J Biol Chem 272: 30299-30305, 1997.

22. Strasberg RM, Zangemeister-Wittke $U$ and Rieber M: p53independent induction of apoptosis in human melanoma cells by a bcl-2/bcl-xL bispecific antisense oligonucleotide. Clin Cancer Res 7: 1446-1451, 2001

23. Tortora G, Caputo R, Damiano V, et al: Combined blockade of protein kinase A and bcl-2 by antisense strategy induces apoptosis and inhibits tumor growth and angiogenesis. Clin Cancer Res 7: 2537-2544, 2001.

24. Zangemeister-Wittke U, Leech SH, Olie RA, et al: A novel bispecific antisense oligonucleotide inhibiting both bcl-2 and bcl-xL expression efficiently induces apoptosis in tumor cells. Clin Cancer Res 6: 2547-2555, 2000. 